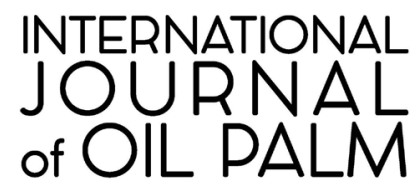

Volume 4, Number 2, 2021

Page 46-57

DOI:10.35876/ijop.v4i2.66

ISSN: 2599-3496 print

ISSN: 2614-2376 online

\title{
The Readiness of Self-Manage Oil Palm Farmers at Sekadau District in ISPO Implementation
}

\author{
Eka Jaya Soebirin, Maswadi*, Anita Suharyani \\ Universitas Tanjungpura Pontianak, Pontianak 78124, Indonesia
}

\begin{abstract}
Based on data from the Directorate General of Plantations in 2018, the tendency of expanding the acreage of self-contained oil palm plantations is continuing. It is feared that the continued expansion of land by both companies and smallholder plantations could cause natural damage and gas emissions that lead to the loss of biodiversity. This has led to a lot of criticism from various parties stating that the palm oil industry is responsible for all the risks that occur. To overcome this, the government implements a governance system (certification) for the entire palm oil industry. Indonesian Sustainable Palm Oil (ISPO) is a certification system issued by Indonesian government to reduce the negative impacts of land expansion and to achieve sustainable palm oil. In its implementation in the field, the implementation of ISPO encounters several obstacles, particularly independent plantations such as difficult and complex legality issues, lack of knowledge that causes a lot of land clearing by burning and continuous land expansion. This research needs to be conducted to see the readiness of independent oil palm smallholders in implementing ISPO with descriptive methods and gap analysis. This research was conducted in Engkersik Village, Sekadau Hilir District, Sekadau Regency, the method of determining the sample was using slovin, amounting to 31 farmers. ISPO consist of 4 principles, criteria and indicators are used as variables in this study. The analysis results of all the principle show that farmers are ready with a readiness percentage of $60.9 \%$, where each principle's percentage of The Legality of Self-Manage Plantation is $75 \%$, The Organization of Farmers and Management of Self-Manage Plantation is $62 \%$, Environmental Management and Monitoring is $43 \%$, and Continuious Business Improvement is $58 \%$, although there are still gaps in its application. For this reason, it is necessary to carry out more effective socialization and training to farmers to minimize the gap.
\end{abstract}

Key words: criteria, gap analysis, indicators, principles

\section{INTRODUCTION}

The growth of oil palm in Indonesia is not only in company plantations but also in smallholder plantations. Based on data from the Directorate General of Plantations (2018), the total area of oil palm plantations in Indonesia reaches 14.0 million hectares with 5.6 million hectares (40\%) are community plantations (Sokoastri et al. 2019).

Corresponding author:

Agribusiness Study Program, Faculty of Agriculture,

Universitas Tanjungpura Pontianak, Pontianak 78124, Indonesia

E-mail: maswadi@faperta.untan.ac.id 
The tendency to expand the area of plantations continued to increase from 1980 to 2015 from 294.56 thousand hectares to 11.30 million hectares, and the growth occurs in the area of smallholder plantations by 46.85 percent per year. This led to many criticisms of land expansion from the palm oil industry which is considered responsible for deforestation, carbon emissions, and loss of biodiversity (Pearce 2017). Most of the expansion carried out by smallholders includes self-manage without paying attention to appropriate plantation cultivation rules due to the lack of information and knowledge of farmers (Maruli 2017).

To reduce the risk of damage to natural resources and the environment, all oil palm plantation businesses are required to apply the principles of good industrial management. In Indonesia, the government is trying to suppress this problem by implementing a management system (certification) for plantations so that it can be widely and easily applied for private plantations, industry, and smallholder oil palm farmers.

Indonesian Sustainable Palm Oil (ISPO) was proposed as an initiative to suppress the problems that occur. Referring Presidential Regulation No. 44 of 2020 states that all oil palm plantation business actors are required to have ISPO certification and smallholder farmers specifically are required to have ISPO certification within 5 years from the issuance of the Presidential Regulation. Business actors who do not have ISPO certification will be subject to sanctions in the form of written warnings, fines, temporary suspension from oil palm plantations, suspension of ISPO certification and/ or revocation of ISPO certification. For oil palm farmers, self-manage certification will be very necessary because it will affect the supply priority by the company. Fresh Fruit Bunches (FFB) produced by self-manage oil palm farmers are considered unfavorable because it is not clear where the seeds come from and how they are harvested. Therefore, independent oil palm farmers need to obtain certification to be in the supply chain to get the same certainty and attention from companies in terms of receiving FFB (Indonesian Biodiversity Foundation 2019).

The facts on the field show that the number of self-manage oil palm smallholder cooperatives participating in ISPO certification is not more than 10 cooperatives throughout Indonesia until 2017 (Dharmawan et al. 2019). Several problems in the ISPO application process faced by independent oil palm smallholders such as land legality issues that are difficult and complex, problems with seeds that are not from certified institutions to environmental issues that are very obscure to farmers so that land clearing is still by burning which leads to many cases, land fires (Purnomo et al. 2017).

People's plantations are spread over several sub-districts such as: Sekadau Hilir District (15,192 ha), Sekadau Hulu (3,976 ha), Nanga Taman (1,811 ha), Nanga Mahap (25 ha), Belitang (344 ha), Belitang Hulu (15,635 ha) and Belitang Hilir (89 ha). Sekadau Hilir is the sub-district with the second largest land area in Sekadau Regency but its production occupies the first position with 38,351 tons, far above other sub-districts (Central Bureau of Statistics 2018).

The implementation of ISPO for sustainable agriculture faces many obstacles such as lack of knowledge, having no legality and land expansion. The rapid expansion of land accompanied by the lack of knowledge regarding good management practices will cause many 
problems such as forest fires, environmental pollution, and low productivity, therefore this research was carried out. The results of the study will determine how far the readiness of independent oil palm smallholders in the implementation of ISPO.

\section{MATERIAL AND METHODE}

This research was conducted in Engkersik Village, Sekadau Regency, there are a many of self-manage oil palm farmers in Engkersik Village, namely 106 farmers who had been recorded by the Oil Palm Farmers Union of Sekadau Regency. The purposive sampling technique is used based on certain provisions. The sample was taken using the Slovin method because the population is known with an error tolerance limit of 15\% (Supriyanto \& Iswandiri 2017). The minimum number of samples that can be taken is 31 respondents with the characteristics of respondents are farmers who are already in the productive category which greatly affect the productivity of farmers (Sujaya et al. 2018), the level of education is very important for someone in managing or solving the problems encountered, besides it also affects a person's mindset in accepting and implementing the innovations provided, the experience will encourage a person to connect the things he learns with what he knows and land area shows the level of success of farmers in managing their resources (Riawati et al. 2016).

This research uses qualitative and quantitative descriptive method design with gap analysis. The data used are primary data obtained through observation and interviews using research questionnaires and descriptively seeking explanations according to facts that will later be analyzed (Putu et al. 2017).
Secondary data were obtained from the Central Statistics Agency, the Plantation Office of Sekadau Regency and the Secretariat of Oil Palm Farmers of Sekadau Regency.

The research was conducted by identifying each ISPO indicator applied by farmers using the Microsoft Excel program in the form of a histogram. The research was conducted in two stages, a description of the results and the gap analysis to determine the level of readiness (Crismanto \& MprocgMgnt 2018). To measure each indicator that refers to the Regulation of the Minister of Agriculture No. 11 of 2015 , then each indicator is given a score. The total score obtained by each sample farmer was then averaged and calculated using the gap formula. Farmers are declared ready when they are in the $51 \%-100 \%$ range.

\section{RESULT AND DISCUSSION}

\section{Smallholder Implementation of ISPO Principles, Criteria and Indicators}

The readiness of self-manage farmers in implementing ISPO can be seen from the number of the requirements or rules have been carried out. For oil palm plantations, the self-manage pattern is regulated in the ISPO Principles, criteria and Indicators specifically for self-manage which are contained in Presidential Regulation No. 44 of 2020 and refers to the Regulation of the Minister of Agriculture of the Republic of Indonesia in 2015. The policy includes 4 main things, namely; the legality of the plantation, organization of smallholders and management of the plantation, management and monitoring of the environment and sustainable business improvement. Therefore, to know how much the rules of the policies that have been carried out by farmers in the practice of cultivating their plantations, it is stated in a descriptive description of the 
results of research in the field are as follows:

\section{The Legality of Self-Manage Planta- tion}

ISPO is intended to regulate and overcome the negative parts of the rapid expansion of land carried out, the application of good cultivation processes, to the problem of deforestation and environmental pollution caused by weak supervision of forest areas and conversion of forest to oil palm without going through complex and easy-to-pass procedures. (Setiawan et al. 2016) in addition, the expansion of land in unoccupied areas is also caused by the high demand for oil palm (Varkkey \& Choiruzzad 2018). One of the requirements to achieve ISPO is to fulfill all the principles set out, one of which is the Legality of Independent plantation. The legality of the land is indicated by the existence of a land title certificate (Brandi et al. 2013). The principle of legality of self-manage plantation has 2 criteria, namely; (a) Legality and management of plantations (b) Location of plantations, the two criteria, there are 4 indicators. From the scheme for ISPO certification, it is expected that all self-manage oil palm plantations can be certified (Brandi et al. 2013). Below is details regarding the level of application of independent oil palm

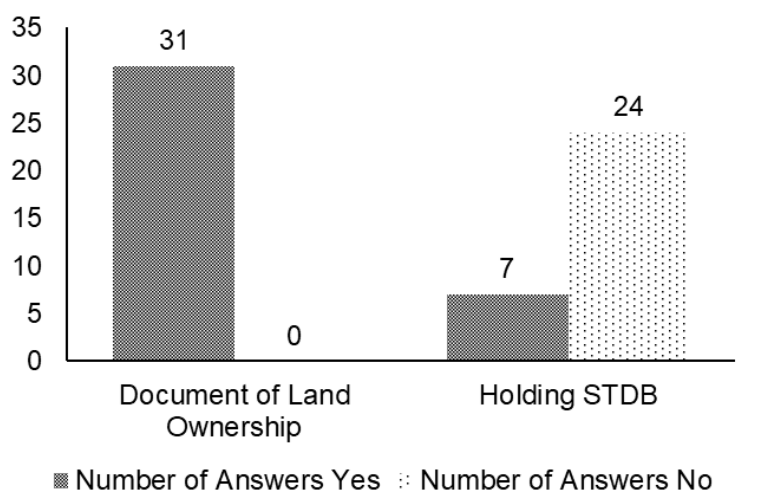

Figure 1 Criteria for legality and management of Sadaya estates. smallholders to the indicators of the legality of independent plantations.

Figure 1 shows of the two indicators that exist in the criteria for legality and self-manage plantation management, only proof of land ownership have been implemented properly by $100 \%$ (31) farmers, in the form of land ownership certificates obtained through the National Agrarian Operations Project. Meanwhile, in the registration certificate for plantation business for cultivation (abrev. in Indonesian: STDB) only $22.5 \%$ (7) farmers have STDB independently, the rest are only temporary STDBs in farmer groups. Most of the farmers who do not have STDBs are caused by several things, such as the lack of knowledge of farmers about STDBs and delays from the relevant agencies in issuing STDBs. Therefore, the criteria for legality and self-managed plantation management show a gap because of the two indicators set by the government, only one has been implemented, the rest have not been implemented optimally.

Figure 2 shows two indicators contained in the location criteria for planters, namely access to FFB collection and local spatial planning provisions have been implemented well by $100 \%$ (31) farmers. The transportation process from the location to the collection point is carried out on the same day and uses appropriate tools such as

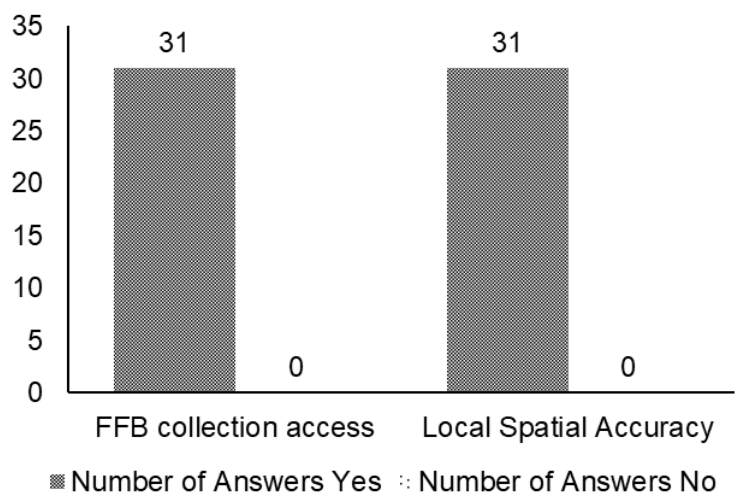

Figure 2 Criteria for farmers location. 
carts and private vehicles specifically for transportation and the status of the land are declared valid under the forestry law because it is in a non-cultivated area, forestry area and other use areas. This is supported by evidence of land ownership and most of the cultivated land is private land originating from former fields, rice fields or small forests that are not classified as protected forests. So from the criteria for the location of the planters, it shows that there is no gap because all indicators have been applied.

\section{Organization of Farmers and Mana- gement of Self-Manage Plantation}

The principles of the organization of planters and environmental monitoring contained in the Regulation of the Minister of Agriculture No. 11 of 2015 consist of 10 criteria, namely; (a) Institutional organization of independent smallholders, (b) Land clearing, (c) Seeding, (d) Planting on mineral soils, (e) Planting on peatlands, (f) Plant maintenance, (g) Control of plant-disturbing organisms, (h) Harvesting, (i) Transportation of fresh fruit bunches, and (j) Sales and agreement on prices of fresh fruit marks. Of the 10 criteria, 29 indicators that are questions for the 31 sample farmers. More details on the level of application of indicators from the principles of smallholder organization and management of independent smallholdings by sample farmers can be seen in the following figure.

From Figure 3 , it can be seen of the organizational criteria for self-manage plantation, of the four indicators that have been determined, only two indicators have been implemented by farmers properly. This is due to several factors such as the production quantity, the management of the farmer group has never explained for the formation document but there is a division of labor. This is because most of the farmer groups have only formed a board of directors and there is no work plan document (Yusmini \& Heriyanto 2017). From the organizational criteria for self-manage plantation, there is a gap due to only two of four have been implemented, and the other two indicators have not been implemented optimally.

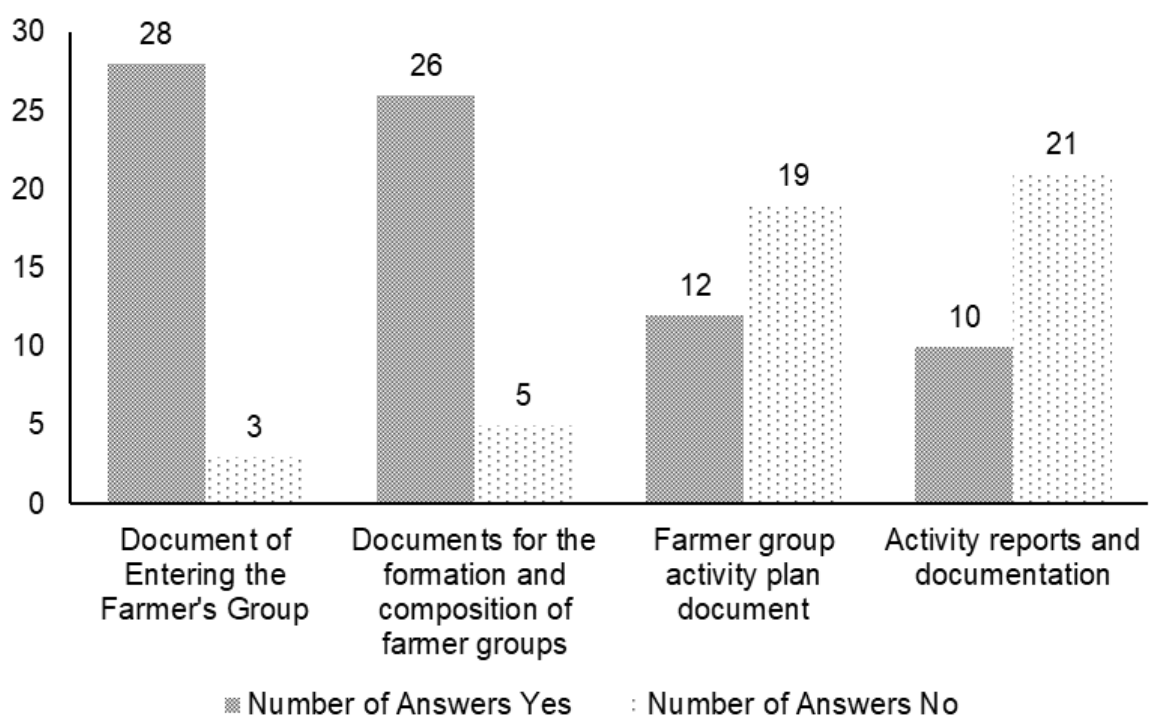

Figure 3 Institutional organization of self-manage plantation. 


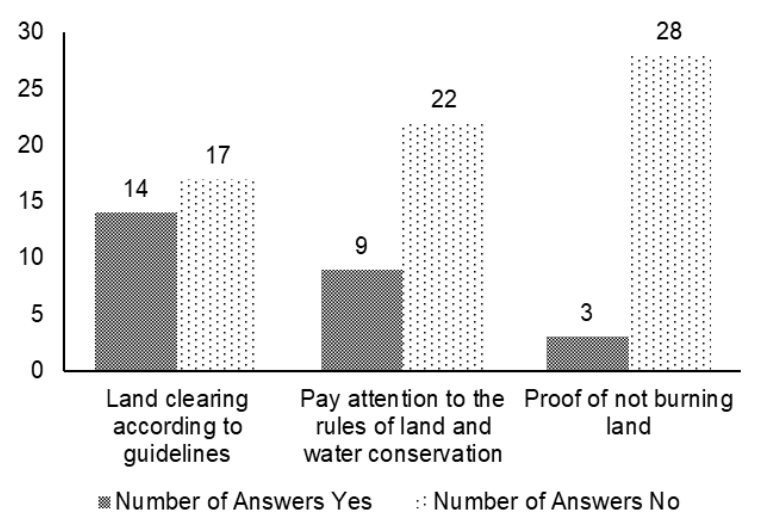

Figure 4 Land clearing criteria.

Figure 4 shows that the three indicators contained in the land clearing criteria have not been implemented properly by farmers. This is due to various factors, such as farmers unawareness of the prohibition against burning (Nuryanti et al. 2019), the lack of information about the regulations issued by the government, and the lack of access to information, technology and finance for farmers are inhibiting factors in achieving certification (Hutabarat et al. 2018). From the land clearing criteria, none of the indicators that have been set have been applied optimally.

Figure 5 shows there are three indicators of seeding criteria where all indicators have been implemented well by most of the farmers. This is stated by the fact that the oil palm seeds that farmers plant are obtained from Parindu (certified institution) which has guaranteed the implementation of the nursery and the origin of the seeds. The seeding criteria, it shows that all indicators have been applied even though there are still gaps, because there are still some respondents who do not have certified seeds, follow the rules during seeding, and record the origin of the seeds.

Figure 6 shows that the criteria for planting on mineral soils have been applied by most of the indicators set out by most of the farmers for which the

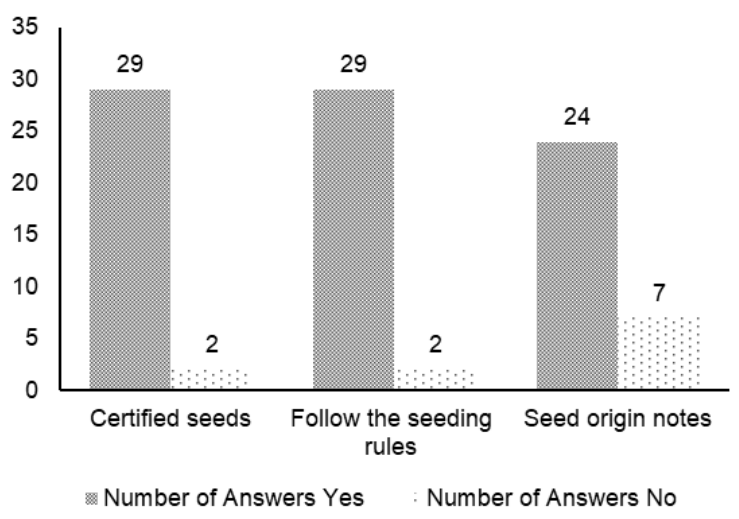

Figure 5 Seeding criteria.

indicator of planters carrying out planting under good cultivation technical guidelines (GAP) and indicators of availability of planting implementation records show the same thing, namely $51.6 \%$ (16) of farmers have implemented it because the implementation of planting that farmers do mostly follows the company's way and has learned during the training, but most of the independent oil palm smallholders keep recording their plantings (Azizah et al. 2020). For planting on mineral soils, all indicators have been applied by most farmers, although there are still less than $50 \%$ of farmers have not implemented them.

Figure 7 shows two indicators contained in the criteria for planting on peatlands. Most farmers have not implemented them well. This is because peatland processing requires a large amount of

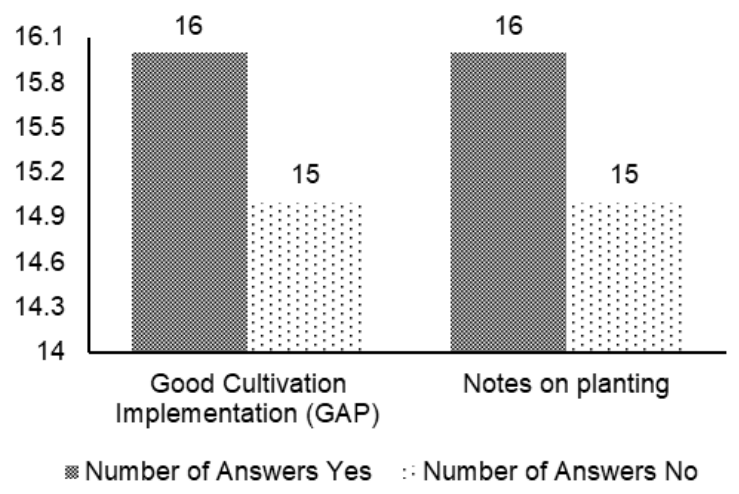

Figure 6 Planting criteria on mineral soil. 


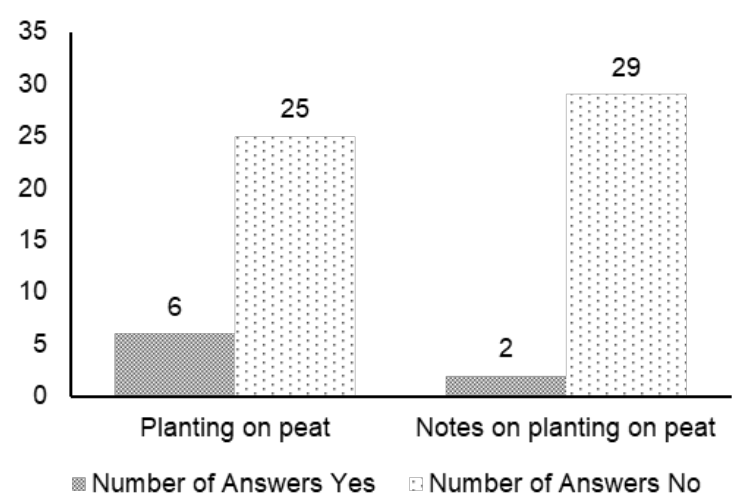

Figure 7 Planting criteria on peat land.

money which makes farmers reluctant to plant on peatland, so they do not even record it. Only a small percentage or less than $20 \%$ of farmers plant and keep records because they have sufficient funds. For planting on peatlands, it can be seen that there is a gap that is indicated by the fact that the two indicators have not been implemented properly.

Figure 8 shows that of the two indicators contained in the criteria for plant maintenance, only $58.1 \%$ (18) farmers have notes regarding plant fertilization that have been applied while the indicators for the implementation of plant maintenance show that only $16.1 \%$ (5) of farmers have implemented it because there are still many farmers carry out plant maintenance depending on land

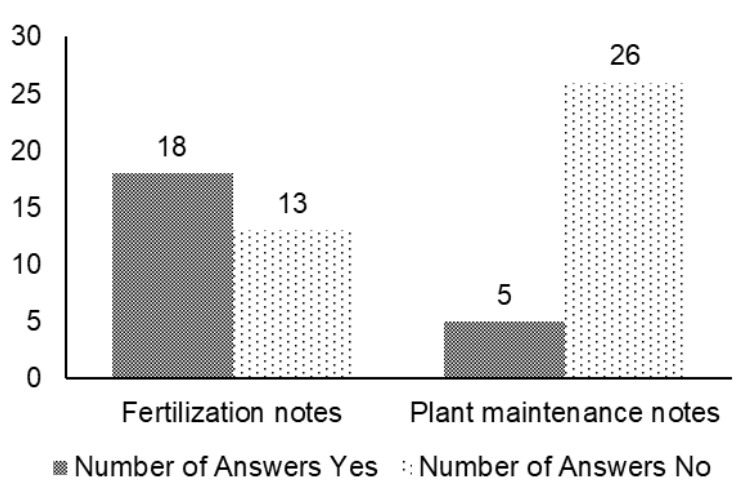

Figure 8 Plant maintenance criteria.

conditions and financial conditions so that recording is rarely done. From the crop maintenance criteria, there is still a gap because only one indicator has been applied and the other indicators have not been implemented.

Figure 9 shows five indicators for controlling plant-disturbing organisms, only three have been implemented properly by most farmers, namely the indicator of technical instructions for work instructions for using pesticides, Most of the farmers do not apply due to several reasons such as only based on experience, implementation is carried out by other people (labor workers), do not know that there are other pest controllers on the land, and because of limited capital for financing. The criteria for controlling plant pest organisms there

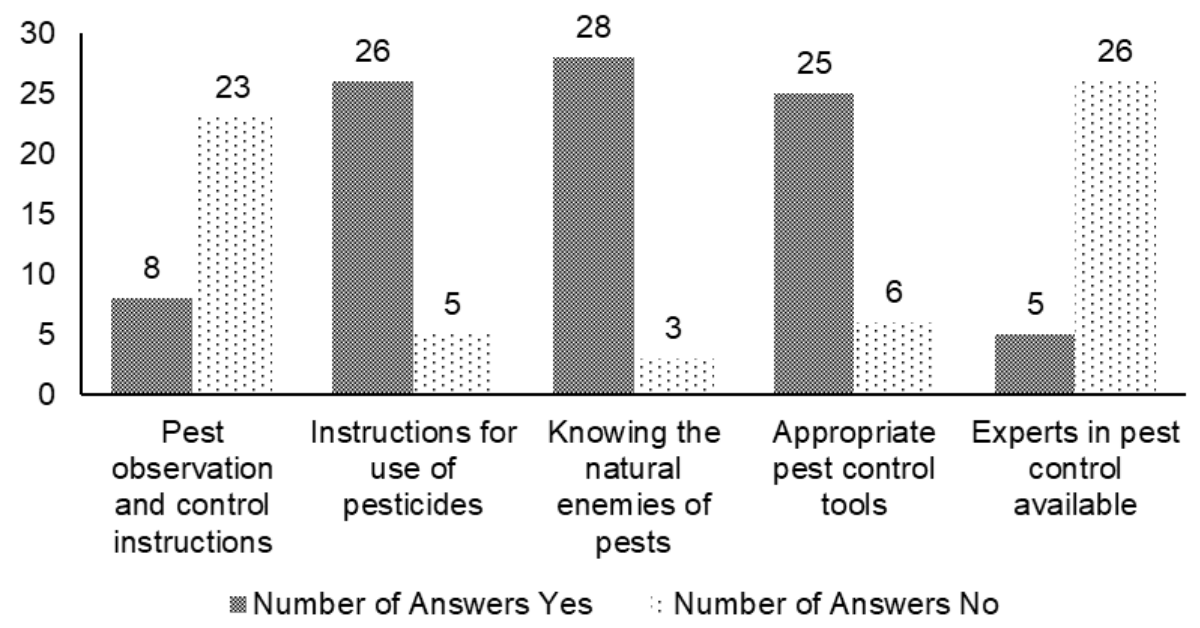

Figure 9 Criteria for control of plant pest organisms. 
is still a gap because of the five indicators that have been set, only three have been applied by most farmers and the other two indicators have not been fully implemented by farmers.

Figure 10 shows the harvesting criteria of all indicators have been applied by some farmers where fruit harvested is ripe fruit.This is stated by the existence of strict standardization rules from the company if it does not meet the maturity standard it will not be accepted and every harvest time is recorded and directed directly by the farmer group which is done 2 times a month. However, less than $10 \%$ of other farmers did not implement it due to several reasons such as harvester errors in assessing the maturity level of the fruit and not joining the farmer group.

Figure 11 shows that there are two indicators criteria for the transportation of fresh fruit bunches, namely available records of the number of FFB transportation and the destination factory has been applied by $93.6 \%$ (29) farmers, and using good transportation and supporting tools shows $100 \%$ (31) farmers have implemented it well because each process of fruit transportation and delivery is coordinated directly by the management of the farmer group, starting from the number

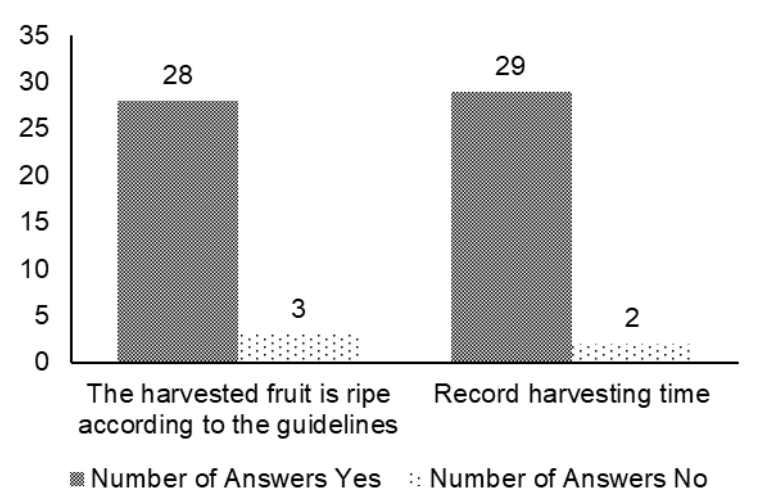

Figure 10 Harvesting criteria. of FFB, tonnage to the number of fruits that are sorted. For transporting fresh fruit bunches, all indicators have been implemented well by farmers, although less than $10 \%$ of other farmers have not implemented them on the grounds that recording is not done because they only rely on memory.

From Figure 12, it can be seen that in the sales and price agreement have been applied by most of the farmers where the indicator shows that there is a sign of FFB delivery to the factory and the indicator is that FFB acceptance documents are available either according to or not in following the requirements, indicating 100\% (31) farmers have implemented as well as the indicator of the availability of FFB price determination documents from the factory and the indicator of the availability of purchasing documents by the company shows that $90.3 \%$ (28) farmers have implemented it. This is stated by the delivery letter obtained from farmer groups, cooperatives or CV, and the price determination issued by the factory every month. There is no gap in the sales and price agreement because all indicators have been applied, although less than $10 \%$ of other farmers have not implemented it on the grounds of selling to brokers.

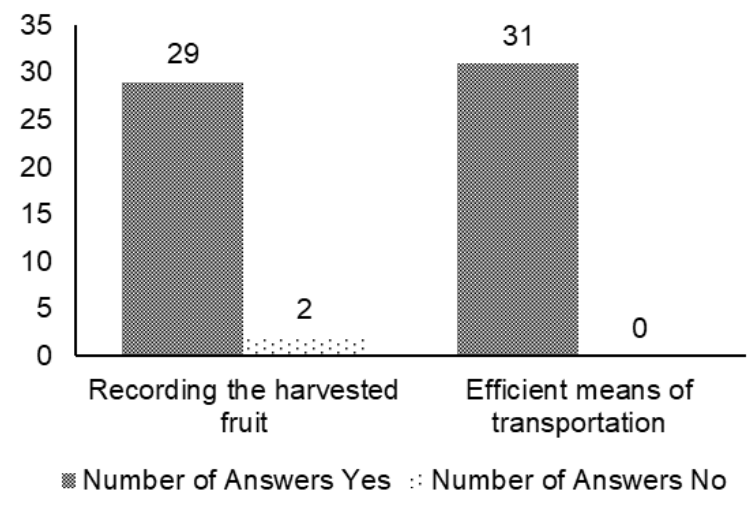

Figure 11 Criteria for transporting fresh fruit bunches. 


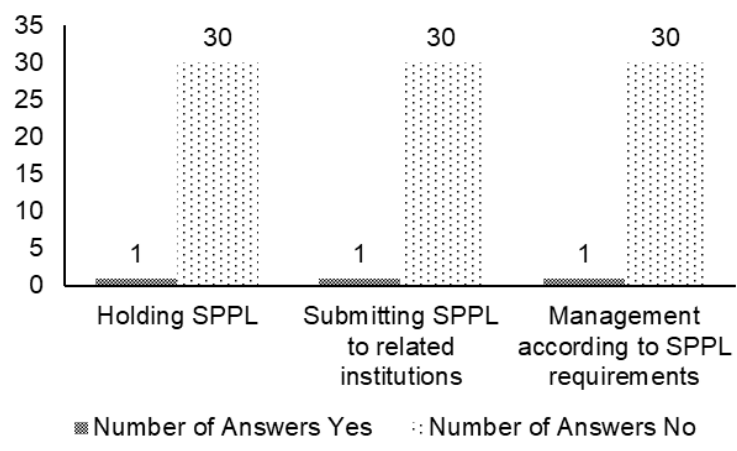

Figure 13 Environmental permit criteria.

\section{Environmental Management and Monitoring}

The principle of environmental management and monitoring contained in the Minister of Agriculture Regulation No. 11 of 2015 has 3 criteria, namely; (a) Environmental permits, (b) Fire prevention and control, and (c) Biodiversity conservation and from the three criteria, there are 7 indicators that become questions for the sample farmers. This principle aims to reduce the risks posed by a series of business or development activities on the environment (Dharmawan et al. 2019). The figure shows details regarding the level of application of independent oil palm smallholders to the ISPO principles, criteria and indicators.

Figure 13 shows all the indicators on environmental permit criteria have not been applied by most farmers. The indicator of making environmental management and monitoring letters (abrev. in Indonesian: SPPL), the indicator submits the SPPL to the relevant institution which shows only a few farmers who already have SPPL and record indicators the application of SPPL is only applied by $3.2 \%$ (1) farmers. This is due to lack of information about SPPL for farmers, so that farmers do not have it and do not know how to make it. The environmental permit criteria show a gap because most farmers have not implemented it yet.

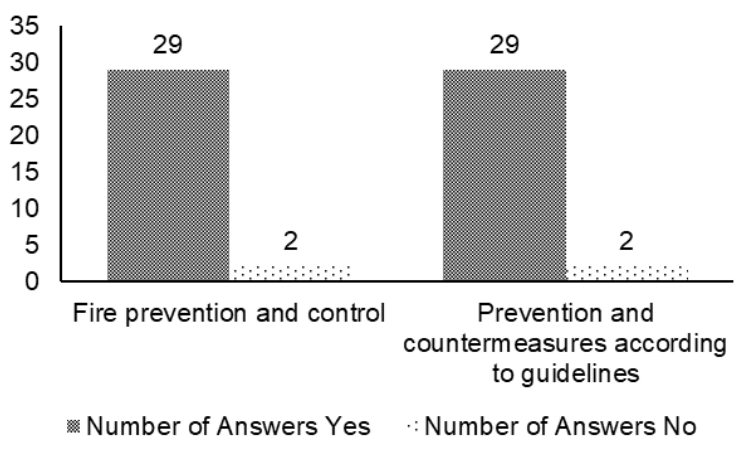

Figure 14 Fire prevention and control criteria.

Figure 14 shows the criteria for preventing and overcoming fires. All indicators have been applied by most of the farmers. The indicators of implementing fire prevention and control with the surrounding population and related agencies, and indicators that are in following the guidelines for fire prevention and control have been applied by $93.6 \%$ (29) farmers. There is no gap in the criteria for fire prevention and control, although there are still less than $10 \%$ of farmers who have not implemented it due to rare participation in farmer group activities and fire patrols.

Figure 15 shows the criteria for biodiversity conservation are only indicators of knowing the presence of animals and plants in the area around the garden either. This is due to several reasons, such as land originating from fields or rice fields and land clearing by other people (labor workers) causing many farmers not to know and record the animals or plants on their land. These criteria show that there is still a gap because only one indicator has been applied from the two indicators that have been set.

\section{Continuous Business Improvement}

The principle of sustainable business improvement is expected to bring good, environmentally friendly and sustainable oil palm plantations. ISPO is present as a tool to increase the production and quality of Indonesian palm oil so that it is in line 


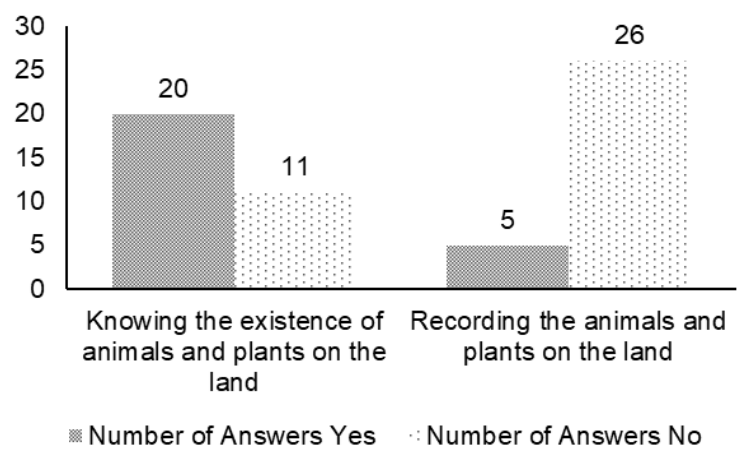

Figure 15 Criteria for conservation of biodiversity.

with the demands of sustainable development (Brandi et al. 2013). The principle of sustainable business improvement consists of one criterion, namely the sustainable increase in oil palm production by all elements and there is one indicator as a question for the sample farmers. Sustainable business improvement is that farmers, farmer groups, cooperatives are guided by other related institutions to continue to improve social, economic and environmental performance such as developing and implementing every activity that supports increasing productivity in a sustainable manner (Yusmini \& Heriyanto 2017). More details on the level of application of farmers to the indicators of the principle of sustainable business improvement can be seen in the following picture.

Figure 16, it can be seen that the criteria for sustainably increasing oil palm production by all elements show that indicators of improvement and improvement have been implemented by $58.1 \%$ (18) farmers. Most farmers already understand in implement sustainable business which is evidenced by the large number of farmers who have recorded improvements or increased yields of their gardens. There is no gap in this criteria although about $41 \%$ of other farmers have not implemented it in practice, farmers prioritize work and put aside recording, the rest only rely on memory.

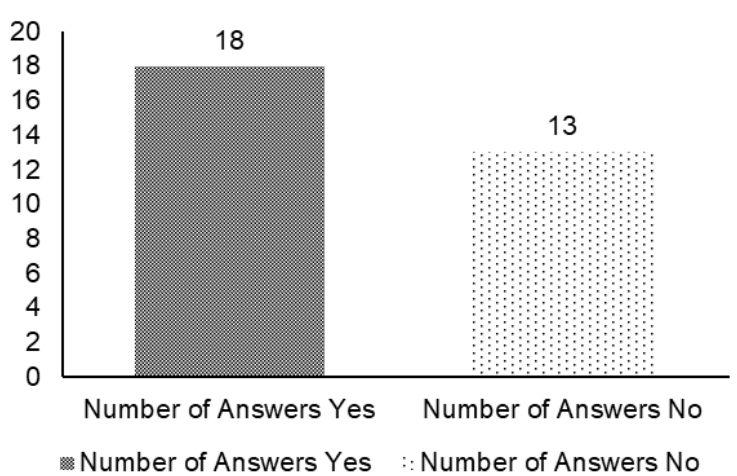

Figure 16 Criteria for sustainable oil palm production increase by all elements.

\section{Gap Analysis for Farmers Readiness}

To determine the level of readiness of self-manage oil palm farmers in the application of ISPO, this study uses gap analysis. This analysis aims to see the gap between expectations (principles, criteria and indicators of ISPO) and reality (the implementation that has been done by farmers). Interviews and questionnaires were conducted to determine the extent of farmers' knowledge of ISPO and its implementation. The questionnaire consists of 41 questions adopted from the ISPO indicators for independent smallholders.

The gap analysis was carried out by determining the maximum expected score of 41 scores. The maximum score is a government decree in the Minister of Agriculture Regulation No. 11 of 2015 concerning ISPO principles, criteria and indicators for independent plantations and has been adapted to field conditions. Of the 31 farmers who became the sample, all answers will be averaged and calculated using the gap formula to obtain a percentage of the assessment. The results of the calculation will be compared with the range of percentage assessments to determine the level of readiness of farmers. The average total score obtained from the 31 sample farmers is 25 scores so that the resulting percentage is $60.9 \%$ (calculation using the gap formula). Based on the results of calculations that have been 
carried out, it shows that the percentage of assessment is in the range of $51 \%-75 \%$, which means that there are still requirements or indicators from ISPO that have not been carried out properly by farmers in their application, such as the indicator of having a STDB, farmer group activity plan documents, reports and documentation of farmer group activities, land clearing according to guidelines, observing land and water conservation rules, evidence of not burning land, planting on peatlands, planting records on peatlands, maintenance records, pest observation and control instructions, have SPPL, submit SPPL to related institutions, management according to SPPL requirements, and record animals and plants on the land, but some requirements or other indicators have been implemented even though the implementation is not documented, most of the indicators implemented. The food was delivered orally so that no planning or documentation was ever carried out. This shows that with an assessment level of $60.9 \%$ of farmers stated that they are ready to implement ISPO, although there are still gaps in its implementation, it must be accompanied by good training and counseling.

\section{CONCLUSION}

The readiness of self-manage oil palm smallholders in Sekadau Regency in implementing ISPO completed using a gap analysis showed that $60.9 \%$ of the indicators had been applied by smallholders, where each principle's percentage of The Legality of Self-Manage Plantation is $75 \%$, The Organization of Farmers and Management of Self-Manage Plantation is $62 \%$, Environmental Management and Monitoring is $43 \%$, and Continuious Business Improvement is $58 \%$. This indicates that self-manage oil palm smallholders in Sekadau are ready to implement ISPO even though there are still some gaps.

\section{REFERENCES}

BPS. 2018. Kecamatan Sekadau hilir dalam angka. Retrieved from https://sekadaukab.bps.go.id/publication/2018/09/26/5ba11295622a$\begin{array}{lllllllllllll}1 & 3 & 2 & \text { c } & 3 & \text { a } & 1 & 0 & 5 & \text { a } & 3 & 9 & \text { / }\end{array}$ kecamatan-sekadau-hilir-dalam-angka-2018.html.

Azizah, Hadi S, Dewi N. 2020. Analisis penerapan ISPO pada perkebunan kelapa sawit pekebun swadaya di Kota Dumai. J Agrib. 22:1-12.

Brandi C, Cabani T, Hosang C, Schirmbeck $S$, Westermann $L$, Wiese $H$. 2013. Sustainability certification in the Indonesian: benefits and challenges for smallholders. Bonn (DE): Deutsches Institut für Entwicklungspolitik.

Crismanto Y, MprocgMgnt SN. 2018. Analisis kesenjangan terhadap penerapan manajemen mutu ISO 9001:2015 pada CV Tirta Mangkok Merah. J Teknol Inform Indust. I:1-9.

Dharmawan $A H$, Nasdian $F T$, Kinseng $\mathrm{RA}$, Indaryant $\mathrm{Y}$, Indriana $\mathrm{H}$. Roslinawat AM. 2019. Kesiapan petani kelapa sawit swadaya dalam implementasi ISPO: persoalan lingkungan hidup, legalitas dan keberlanjutan. J IImu Ling. 17:309-315.

Pearce F. 2017. Can a deforestation driver become a fores protector? Colombo Sri Lanka: program on water, land and ecosystems.

Purnomo H, Okarda B, Dewayani AA, Ali M, Achdiawan, Kartodiharjo H, Pacheco P, Juniwaty KS. 2017. Reducing forest and land fire through good palm oil value chain governance. Forest Policy Econom. 91:94-106. 
Hutabarat S, Slingerland M, Reitberg $P$, Dries L. 2018. Costs and benefits of certification of independent oil palm smallholders in Indonesia. Inter Food Agribus Manag Review. 21(6):681-700. YKHI. 2019. Studi rantai pasok TBS petani kelapa sawit swadaya. Jakarta (ID).

Maruli P. 2017. Best management practice kelapa sawit. Yogyakarta (ID): Lily Publisher.

Nuryanti S, Hutabarat S, Yusri J. 2019. Analysis on sustainability of oil palm independent (a case study of oil palm independent smallholder kelompok tani petani makmur at Lubuk Ogong Village, Bandar Sei Kijang sub district, Pelalawan). J Sungkai. 7: 61-78.

Peraturan Mentri Pertanian Republik Indonesia. 2015. Sistem sertifikasi kelapa sawit berkelanjutan Indonesia. Jakarta (ID): Permen.

Peraturan Presiden. 2020. Sistem sertifikasi perkebunan kelapa sawit berkelanjutan Indonesia. Jakarta (ID): PP.

Putu AA, Yuesti A. 2017. Metodologi Penelitian kuantitatif dan kualitatif. Denpasar (ID): Abpublisher Yogyakarta.

Riawati, Rosnita, Yulida R. 2016. Karakteristik internal dan karakteristik eksternal petani kelapa sawit di Desa Buluh Rampai Kecamatan Seberida Kabupaten Indragiri Hulu. J Online Mahasiswa UNRI. 3(2):1-10.
Setiawan EN, Maryudi A, Purwanto RH, Lele G. 2016. Opposing interests in the legalization of non-procedural forest conversion to oil palm in central Kalimantan, Indonesia. Land Use Policy. 58:472-481.

Sujaya DH, Hardiyanto T, Isyanto AY. 2018. Faktor faktor yang berpengaruh terhadap produktivitas usaha tani mina padi di Tasik Malaya. J Pemikir Masy Ilmiah Berwawasan Agribis. 4(1):1-15.

Supriyanto W, Iswandiri R. 2017. Kecenderungan sivitas akademika dalam memilih sumber referensi untuk penyusunan karya tulis ilmiah di perguruan tinggi. Berkala IImu Perpus Inform. 13:1-8.

Sokoastri V, Setiadi D, Hakim, Rahman A, Mawardhi AD. 2019. Perkebunan petani sawit rakyat: permasalahan dan solusi. J Sodality. 7:182-194.

Varkkey TH, Choiruzzad S. 2018. Palm oil intensification and expansion in Indonesia and Malaysia: Environmental an socio-political factors influencing policy. Forest Policy Econom. 92:148-159. Yusmini, Heriyanto. 2017. Analisis kesiapan petani kelapa sawit swadaya dalam penerapan ISPO di Kabupaten Indragiri Hilir. SEMNAS Univ Riau. 1-9. 